procedure, which enables preparation to be made, would not be much of a linguistic feat for most mernbers of the Congress and would add greatly to the intelligibility of the proceedings.

There was a universally expressed desire on the part of the members to meet in England at some future date in order to see the classic sections of East Anglia and Yorkshire.

\section{Contributions of Chemistry to Pharmacy and Medicine}

$\mathrm{T}$

HE Hanbury Gold Medal of the Pharmaceutical Society of Great Britain, which is awarded for "high excellence in the prosecution or promotion of original research in the Chemistry and Natural History of Drugs", was presented to Dr. F. Pyman at the opening of the School of Pharmacy on October 7.

Dr. Pyman afterwards delivered the inaugural sessional address, in which he reviewed the contribution made by chemistry to pharmacy and medicine during the twentieth century. He pointed out that whereas medicine has contented itself for many thousands of years with the use of drugs of animal, vegetable and mineral origin and of their simple extracts, it is only within a comparatively short period of the world's history-barely 130 yearsthat the development of organic chemistry and other sciences has enabled these crude drugs and pharmaceutical preparations to be replaced in many instances by principles isolated from them in the form of pure chemical compounds. This tendency has been reflected in the diminution in the number of crude drugs and galenical preparations included in successive British Pharmacopœias. This isolation of the pure active principles of drugs has been of importance not only as an end in itself, but also as a means of giving the organic chemist opportunities of working on the constitution of these compounds both analytically and synthetically.

Expense may prevent the widespread substitution of the synthesized product for that obtained from natural sources but, Dr. Pyman noted, the improve. ment in the methods for the production of tropinone by Robinson is at least one example of a laboratory synthesis which has brought the time appreciably nearer when both atropine and cocaine may be commercially available as synthetic products. The extraction of chemical constituents of vegetable drugs has stimulated the search by biochemists for the active principle of biological products. Raw liver taken by sufferers from pernicious anæmia over long periods caused nausea, and many patients were unable to continue the treatment. The work of Cohn led to the introduction of a method by which the activity present in the original liver could be concentrated in a fraction which represented about one thirtieth of the original bulk, while further work has enabled still more concentrated preparations to be made. Attempts to effect still further concentration and to isolate the active principle are making slow progress, firstly owing to the instability of the active principle and secondly to the fact that there is no satisfactory animal test for its efficiency in pernicious anæmia.

The consideration of these researches led Dr. Pyman to review the development of chemotherapy, research in which postulates co-operation between chemist and biologist. It is a commentary upon the difficulties in this field of research that the pioneer work of Ehrlich and Bertheim in 1907 still remains the outstanding example of the application of chemotherapeutic principles. That the laboratory worker will steadily add to the products available for the physician is certain, and there is no doubt that in many directions laboratory products will produce results not otherwise attainable. Nevertheless, the isolation of an active principle does not mean tho death of the original vegetable or biological product. Tincture of nux vomica, tincture of digitalis or extract of ergot will have their place in medicine and may well produce physiological effects which cannot be obtained by their isolated active principles.

\section{Educational Topics and Events}

Cambridge.-The Central Committee for Agricultural Research Organizations has appointed $\mathrm{H}$. Hunter, of St. Catharine's College, to be director of the Plant Breeding Institute in succession to Sir R. H. Biffen.

The director of the Solar Physics Observatory has made the following appointments: W. Moss, to be first senior observer, J. C. Dobbie, of Trinity College, to be second senior observer, E. G. Williams, of Trinity College, to be first junior observer.

Oxford.-Dr. H. M. N. H. Irving, of Queen's College, has been appointed tutor in natural science at St. Edmund Hall-a new appointment.

Mr. Alec Naylor Dakin, formerly Lady Elizabeth Hastings Scholar of Queen's College, has been elected to the Lady Wallis Budge Fellowship in Egyptology at University College. Mr. Dakin was educated at Heath School, Halifax, and was placed in the first class in Classical Honour Moderations and in the second class in the Final Honour School of Literce Humaniores.

The Right Hon. W. G. A. Ormsby-Gore has been elected to an honorary fellowship at New College. Mr. Ormsby-Gore's work when Under-Secretary of State for the Colonies in a former administration, as well as his archæological writings, which have achieved a wide success, and his work in the preservation of ancient monuments while acting as Chief Commissioner of His Majesty's Office of Works, thus receive well-deserved academic recognition.

Sheffield.-The following appointments have been made : Dr. R. Rado, to be assistant lecturer in mathematies; Mr. T. L. Morgan, to be assistant lecturer in civil engineering; Dr. W. A. Kirkby, to be lecturer in fuel technology.

THE formal opening of the thirty-fifth session of the Sir John Cass Technical Institute took place on the evening of October 6, when an address was delivered by Bishop Paget to those assembled in the Great Hall, which forms a part of the recently erected extension of the Institute. The chairman of the Governors, the Rev. J. F. Marr, who presided, remarked that during the past two sessions, in which the additional accommodation provided by the extension has been in use, the volume of work has increased 15 per cent. This continued expansion is creating a new demand for additional laboratory accommodation for chemistry and biology, and also for lecture rooms for chemistry and physics 
capable of seating more than 70 students. The policy of fostering research has been followed consistently throughout the history of the Institute and during the past session 35 students were engaged in this type of work. In discussing the financial help which the Institute has received, Mr. Marr referred particularly to the generous support of several of the important oil companies in connexion with the courses in petroleum technology. New developments of the present session include advanced courses in botany of final degree standard and post-graduate courses in biochemistry and chemical engineering. An extension of the course in bacteriology will give additional facilities for post-graduate work. The Principal, Mr. Geo. Patchin, said that, of the 62 students successful at London post-matriculation examinations, 1 obtained the degree of Ph.D., 10 the degree of M.Sc., 5 the B.Sc. dogree with first class honours, 6 the B.Sc. degree with second class honours, 15 the pass degree and 1 the B.Sc. Engineering (Metallurgy) degree with first class honours.

\section{Science News a Century Ago}

\section{Caroline Herschel and Sir John Herschel}

ON October 20, 1836, Caroline Herschel, then eighty-six years of age, wrote from Hanover to Sir John Herschel at the Cape. In the course of her letter she said : "I have four complete years of the 'Astronom. Nachrichten' ready bound for you. . . . I wished to give you the number of the paper (but cannot find it again) where Bessel speaks of Saturn's satellites, but my eyes are so dim and I am too unwell for doing anything. I will therefore only say he has seen the 6 th but not the 7 th, the ring being in the way. In No. 293 two of Bessel's assistants, Beer and Mädler, say a great deal about the observations of your father, but that goes for nothing. I will only say in general that he did in one season more than any one else could have done, and would have resumed the hunt the next fifteen years if nothing had interfered. And the Georgium Sidus was followed as long as anything could be obtained from that planet, and it will yet be some twenty years before he will be in that favourable situation in the ecliptic where he was at the time the satellites were discovered. . . ."

Warwickshire Natural History and Archæological Society

According to the Analyst (5, 303), the first quarterly meeting of the members of the above society was held at Warwick on October 22, 1826, Sir H. Dryden, Bart., being in the chair. After some preliminary remarks by the chairman, the gathering was addressed by Dean Buckland, who is reported as saying that "the walls of Warwick Castle, the walls of the town, and the walls of the cathedral, were composed of strata till recently unknown to geologists. He saw them twenty years ago, but he did not know what was their composition, but still in his travels he had borne in mind the remains of the animals contained in the strata, in the hope that the time might come when the darkness in which these fragments were eclipsed would be dissipated ; and when he should be able to make some important discovery to the scientific world. It was a matter of gratification to him that within the last two hours that darkness had dissipated; and he was now able to say that in Warwick-under their feet- and on Guys'-cliff there were the remains of many extinct species and genera of animals, whose names were as yet unuttered in England. . . . He ventured to say with as much confidence as if endowed with the spirit of prophecy, for he knew from geological inspection, and from example added to example, that under this town, Leamington and the surrounding neighbourhood, were the remains of thousands of Elephants, of Rhinoceroses, of Tigers, of Buffaloes, and a variety of other animals which he could enumerate."

\section{Ehrenberg's Microscopical Discoveries}

IN its column of "Miscellanea", the Athenceum of October 22, 1836, said : "M. Alexandre Brongniart writes from Berlin that a discovery has been made by M. Ehrenberg of a very interesting nature. It is, that the homogeneous rocks, which are not very hard, but friable, easily split, entirely composed of silex, and known under the name of Tripoli, or the Polierschiefer of Werner, are entirely composed of perfectly recognizable skeletons of infusory animals, of the family Bacillaria. . . . These remains having perfectly retained their forms, the siliceous carcases of these infusoriæ are to be seen very clearly in the microscope, and may be easily compared to the living animals as observed and delineated by $\mathbf{M}$. Ehrenberg. In many instances there are no appreciable differences. The species are determined by the form, and more surely by the number of chambers or transversal lines which divide these minute bodies. M. Ehrenberg has been able to count them, by aid of the microscope, and has recognized the same number of divisions in the living and the fossil species."

\section{Spontaneous Combustion}

The Medico-Chirurgical Review of October 1836 gives the following account of a case of spontaneous combustion reported in the French Press to have taken place at Aunay in the Department of Avalon : "A very fat woman, aged 74 years, addicted to drinking brandy at 27 degrees, lived alone, and one evening returned home as usual, but, as she did not appear among her neighbours the next morning, they knocked at her door. No answer being returned to repeated demands, they summoned the mayor, who forced the door and exposed a horrible spectacle, accompanied by an extraordinary smell. Near the chimney lay a heap of something burnt to cinders, at the end of which was a head, a neck, the upper part of a body, and one arm. At the other end were some of the lower parts, and one leg still retaining a very clean shoe and stocking. No other traces of fire were to be seen, except a blue flame which played along the surface of a long train of grease, or serous liquor, which had been produced by combustion of the body. The mayor found it impossible to extinguish this flame, and summoned all the authorities; and, from the state of the apartment and comparison of circumstances, it was concluded among them that previous to going to bed, for which she had evidently been making preparations, the woman had been trying to ignite some embers with her breath. The fire communicating with the body by means of the breath, combustion probably took place, and would appear to confirm an opinion entertained by several learned men, that that which is called spontaneous combustion of the human frame never takes place without the presence of some ignited body near the person predisposed to combustion." 